\title{
The importance of frequent follow-up in the first year after pacemaker implantation upon detection of atrial tachyarrhythmia
}

\section{Znaczenie częstych kontroli w pierwszym roku po implantacji stymulatora serca dla wykrywania arytmii przedsionkowych}

\author{
Anna Nowek, Michał Chudzik, Jerzy K. Wranicz \\ Department of Electrocardiology, Medical University of Lodz, Lodz, Poland \\ Head of the Department: Prof. Jerzy K. Wranicz MD, PhD
}

Key words: atrial tachyarrhythmias, implantation, pacemaker.

Słowa kluczowe: arytmie przedsionkowe, implantacja, stymulator serca.

\begin{abstract}
Introduction: Newer pacemakers have data storage capabilities that permit detection of multiple episodes of atrial tachyarrhythmias (AT).

Aim of the research: To document the frequency, time to first AT detection after implantation, and risk factors for symptomatic episodes and to determine the prevalence and predictors of pacemaker-detected AT.

Material and methods: Patients $(n=62)$, from a single centre, with an implanted pacemaker that automatically recorded the cumulative daily AT burden were included in the analysis. The clinical history regarding AT was collected before implantation. Follow-ups were done at 3, 6, and 12 months after implantation with interrogation and symptoms reported from patients. Echocardiography was performed at baseline and at 12 months.

Results: Atrial tachyarrhythmia was detected by the pacemaker in $16(25.81 \%)$ of 62 patients. AT/atrial fibrillation (AF) burden was detected after 3 months in 13 out of 16 (81.25\%) patients, and in 38.46\% of them there was no clinical history of AF. Asymptomatic episodes occurred in 7 patients (43.75\% - 3 men and 4 women), and 2 (28.57\%) of them did not have a clinical history of AF. History of AF prior to implantation was significant for the appearance of AT/AF burden $(p=0.006)$, and use of $\beta$-blockers significantly limited AT/AF burden $(p=0.040)$. Other analysed data was statistically non-significant.

Conclusions: Pacemaker-detection of AT is often the first paroxysmal AT diagnosis in asymptomatic patients. This suggests that AT data, collected from capable pacemakers and frequently reviewed, can lead to new diagnosis and early treatment in that group of patients, which could influence mortality and morbidity.
\end{abstract}

\section{Streszczenie}

Wprowadzenie: Nowe stymulatory serca umożliwiają ciągłą detekcję i zapis epizodów arytmii przedsionkowych (AT). Cel pracy: Zbadanie częstości występowania i czasu do pierwszego rozpoznania AT po implantacji, a także określenie czynników ryzyka pojawienia się objawowych epizodów arytmii.

Materiał i metody: Do badania włączono 62 pacjentów po implantacji stymulatora serca z funkcją automatycznej rejestracji epizodów AT. Przed implantacją zebrano dane dotyczące przebiegu AT u pacjentów. Kontrolę z odczytaniem danych z zaimplantowanego urządzenia oraz odnotowaniem objawów zgłaszanych przez pacjenta przeprowadzono po 3, 6 i 12 miesiącach od implantacji. Badanie echokardiograficzne wykonano przed zabiegiem oraz 12 miesięcy po implantacji.

Wyniki: Arytmie przedsionkowe zostały wykryte przez stymulator serca u $16(25,81 \%)$ spośród 62 pacjentów. U 13 (81,25\%) z nich rozpoznano je już przy pierwszej wizycie - po 3 miesiącach, 38,46\% nie miało wcześniej w wywiadzie migotania przedsionków (AF). Bezobjawowe epizody wystąpiły u 7 (43,75\%) pacjentów, 2 (28,57\%) z nich nie miało w wywiadzie AF. Okazało się, że AF w wywiadzie przed implantacją jest istotnym czynnikiem ryzyka wystąpienia AT/AF $(p=0,006)$, a stosowanie $\beta$-adrenolityków czynnikiem ograniczającym AT/AF $(p=0,040)$. Pozostałe dane były nieistotne statystycznie.

Wnioski: Zapis AT przez stymulatory serca stanowi często pierwszą diagnozę arytmii u pacjentów bez objawów choroby. Dane dotyczące AT gromadzone przez stymulatory serca, które są często przeglądane, mogą prowadzić do nowej diagnozy i wczesnej terapii u tych pacjentów, co może wpływać na zachorowalność i śmiertelność. 


\section{Introduction}

Atrial tachyarrhythmias (AT) are the most common sustained cardiac rhythm disturbances in adults and are the leading cardiac cause of morbidity and mortality [1]. Dual-chamber pacemakers have the ability to document even brief episodes of AT [2]. Most of these episodes are short and asymptomatic and would not be detected by means other than pacemaker [3, 4]. The detection of undiagnosed atrial tachycardia/ atrial fibrillation (AT/AF) could be useful for primary prevention of consequences and complications such as stroke, by including early treatment and intervention [5]. Pacemaker programming undertaken at implantation should be reviewed and changed accordingly at subsequent follow-up visits if AT was detected. As a guideline, the 1984 Health Care Financing Administration document suggests the following for clinic follow-up: for dual-chamber pacemakers, twice in the first 6 months, then once every 6 months [6]. However, in clinical practice visits often take place for the first time 1-3 months after implantation, and then once a year. Current ACC/AHA/HRS Guidelines for DeviceBased Therapy of Cardiac Rhythm Abnormalities recommend transtelephonic monitoring as a good possibility of frequent and extensive patient assessment [7]

\section{Aim of the research}

The aim of this study was to document the prevalence of pacemaker-detected AT in a population of patients from a single centre implanted with dualchamber pacemakers with capability of AT/AF burden storage, with or without history of clinical AF. We sought to document the frequency of AT and time to new diagnosis determined by pacemaker data storage, as well as clinical and echocardiographic risk predictors for the development of pacemaker-detected AT.

\section{Material and methods}

Patients after de novo implantation of dual-chamber pacemakers capable of documenting AT, with or without history of paroxysmal AT, were included into this study. Manufacturer-specific nominal settings for AT detection were typically employed. Exclusion criteria were as follows: replacement devices, long-standing persistent $\mathrm{AF}$, and unable or unwilling to consent. Patients were followed-up at 3, 6, and 12 months after implantation. Diagnostic information with AT/AF burden measurement was collected and the presence of symptoms was noted at every follow-up visit. The following data was analysed: age, gender, body mass index (BMI), NYHA class, indication for implantation (divided into three groups: bradycardia-tachycardia syndrome (BTS), sick sinus syndrome SSS, atrio-ventricular block (AVB)), history of paroxysmal AF, coexisting diseases such as coronary artery disease (CAD), past myocardial infarction (MI), diabetes (DM), hy- pertension (HA), stroke, and pharmacotherapy. Echocardiograms were performed before implantation and 1 year after, and they were interpreted by a single reader blinded to the presence of pacemaker-detected AT. The following echocardiographic measures were evaluated: left and right atrium dimensions (LA, RA), ejection fraction (EF), left ventricular systolic diameter (LVsD), left ventricular diastolic diameter (LVdD), right ventricular diastolic diameter (RVdD), mitral regurgitation (IM), and tricuspid regurgitation (IT). Regarding data retrieved from pacemaker memory, AT/ AF burden \%, atrial pacing \% (AP\%) and ventricular pacing \% (VP\%) were documented at every visit.

\section{Statistical analysis}

The normality of the data set was tested using the Shapiro-Wilk's test. Quantifiable variables were expressed as mean \pm standard deviation (SD) or median and inter-quartile range (IQR) depending on the results of the normality test. Differences between two independent samples for continuous clinical data were analysed using $t$-Student's and Mann-Whitney's $U$ tests. For categorical variables statistical analysis was based on $\chi^{2}$ test and $\chi^{2}$ test with Yates' adjustment. Risk predictors with $p$-value $<0.05$ in univariate analyses were included into a multivariate logistic regression model. The results were considered significant for $p<0.05$. Statistica 10 and SPSS 21 software packages were used to analyse the data.

\section{Results}

\section{Prevalence and frequency of atrial} tachyarrhythmias

Sixty-two patients participated in the study, including $39(63 \%)$ with history of AF prior to pacemaker implantation and 23 (37.1\%) without clinical history of AF. In 18 out of 62 patients indication to implantation was BTS (29\%), in 17 (28\%) patients - SSS, and in 27 (44\%) patients - AV block. The AT was detected by the pacemaker in $16(26 \%)$ of 62 patients. In $10(55 \%)$ out of 18 patients implanted from BTS AT/AF burden was detected, which means that nearly every second patient with clinical history of AF is free from AT during the first year after implantation. However, it is worth mentioning that $5(31 \%)$ patients without clinical history of AF (3 patients implanted from BTS and 2 from AV block) from 16 patients with AT/AF burden had AT episodes during the first year after implantation, so pacemaker-detection of AF was the first paroxysmal AT diagnosis (Figure 1).

\section{Time to detection of atrial tachyarrhythmias}

The AT/AF burden was detected after 3 months in $13(81 \%)$ out of 16 patients. Thirty-eight percent of patients with AT detected within the first 3 months had no previous clinical history of AF. The next 3 cases 


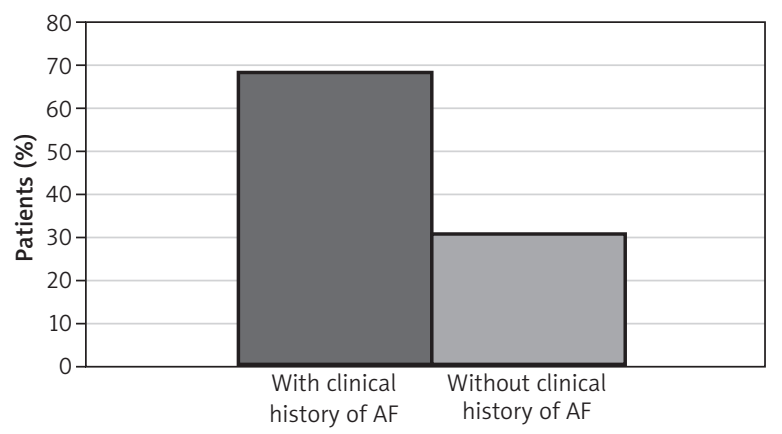

Figure 1. Patients with atrial fibrillation (AT)/atrial fibrillation (AF) burden detected divided into groups with and without clinical history of AF

Table 1. Characteristics of patients with and without pacemaker-detected atrial tachyarrhythmia

\begin{tabular}{|lccc|}
\hline Variable & $\begin{array}{c}\text { No pacemaker } \\
\text { detected AF } \\
(n=46)\end{array}$ & $\begin{array}{c}\text { Pacemaker - } \\
\text { detected AF } \\
(n=16)\end{array}$ & -value \\
Age [years] & 75.65 & 73.63 & 0.384 \\
BMI & 27.67 & 28.72 & 0.435 \\
History of AF & 12 & 11 & 0.006 \\
CAD & 20 & 4 & 0.312 \\
MI & 5 & 2 & 0.778 \\
DM & 12 & 6 & 0.393 \\
HA & 39 & 12 & 0.615 \\
ACEI & 22 & 83 & 0.880 \\
Statins & 16 & 5 & 0.960 \\
Anti- & 4 & 4 & 0.213 \\
arrhythmic & & 2 & 0.962 \\
VKA & 4 & 7 & 0.097 \\
$\beta$-Blocker & 31 & $59 / 49$ & 0.549 \\
LA [mm] & $57 / 46$ & $55 / 40$ & 0.512 \\
RA [mm] & $51 / 38$ & 62.38 & 0.194 \\
EF \% & 64.60 & 30.0 & 0.437 \\
LVSD [mm] & 31.6 & 50.6 & 0.964 \\
LVdD [mm] & 50.8 & 25.8 & 0.516 \\
RVdD [mm] & 26.0 & 42.75 & 0.687 \\
AP\% & 46.87 & 54.25 & 0.588 \\
VP\% & 62.50 & & \\
\hline
\end{tabular}

$B M I$ - body mass index, CAD - coronary artery disease, $M I-$ myocardial infarction, DM - diabetes mellitus, HA - hypertension arterialis, ACEI - angiotensin-converting-enzyme inhibitor, VKA - vitamin $K$ antagonists, $L A$ - left atrium dimensions prior to implantation, $R A$ - right atrium dimensions prior to implantation, $E F$ - ejection fraction, $L V s D$ - left ventricular systolic diameter, $L V d D$ - left ventricular diastolic diameter, $R V d D$ - right ventricular diastolic diameter, AP\% - atrial pacing, VP\% - ventricular pacing.

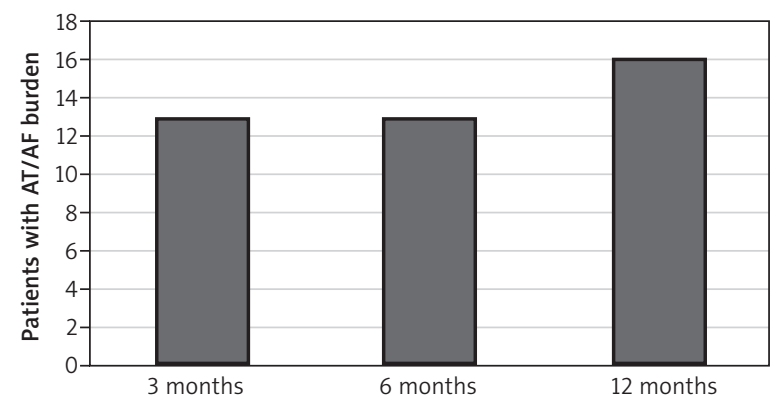

Figure 2. Time from implantation to atrial tachyarrhythmia (AF)/atrial fibrillation (AF) burden detection

of AT/AF burden were detected at 12-month follow-up (Figure 2).

The AT/AF burden percent ranged from $1 \%$ to $100 \%$, mean $23 \%$. In 2 patients with clinical history of AF 1-year follow-up showed permanent AF. Analysis of data stored by pacemaker showed that AT episodes often do not correlate with complaints. Symptoms such as palpitations and dyspnoea at any of the follow-ups were reported in 25 (40\%) out of 62 cases; however, only in 9 cases $(14.5 \%-6$ women and 3 men) was there correlation with the presence of AT. Fifteen $(71.4 \%)$ out of 21 women and 1 (25\%) out of 4 men did not have AT/AF burden detected, so symptoms did not correlate with AT, as could be suggested. Symptoms were significantly more often reported by women than by men ( $84 \%$ vs. $16 \%, p=0.006)$. Asymptomatic episodes (pacemaker-detected AT/AF without symptoms reported from patients during any of the follow-ups) occurred in 7 patients $(43.75 \%-3$ men and 4 women), and $2(28.57 \%)$ of them did not have clinical history of AF.

\section{Risk factors of atrial tachyarrhythmias}

Multivariate analysis showed that history of AF prior to implantation was significant for the appearance of AT/AF burden ( $p=0.006)$. Other clinical factors such as age, BMI, NYHA class, coexisting diseases such as CAD, past MI, DM, HA, and stroke was statistically non-significant, as well as pharmacotherapy except for use of $\beta$-blockers, which significantly limited AT/AF burden $(p=0.040)$. There were no significant differences in echocardiographic parameters (LA, RA dimensions, EF, LVsD, LVdD, RVdD, IM, and IT) between the group with pacemaker-detected AT compared to the no-pacemaker-detected AT group (Table 1). Data retrieved from pacemaker memory: AP\% and VP\%, was statistically non-significant.

\section{Discussion}

The main finding of our study was that newly detected AT/AF during the first year after implanta- 
tion was documented in more than $30 \%$ of patients. Pacemaker diagnostic data with intra-atrial EGMs can diagnose specific AT and identify other pacemakersensed events [8]. The diagnostic accuracy of pacemaker and ICDs with an atrial lead is very high, with appropriate detection of $95 \%$ of AF episodes, while for implantable loop recorders the specificity is about 85\% [9]. Despite the small sample size our findings correlate with other studies with higher numbers of patients included. Ziegler et al. documented that continuous PM-based monitoring identified newly detected AT/AF in 30\% of patients with stroke risk factors, and episodes occurred sporadically, highlighting the difficulty in detecting paroxysmal AT/AF using traditional monitoring methods such as ECG or 24hour Holter ECG monitoring [10]. In a study by Yedlapati et al., which included 728 patients with DDD pacemakers, $26 \%$ out of 66 patients with AF recorded were newly discovered to have AF, which was similar to our finding [11].

In our study AT/AF burden was detected after 3 months in 13 (81\%) out of 16 patients, and in 38\% of them there was no clinical history of AF. The importance of first-year observation was also noted by Nagarakanti et al. The time to first, second, and third persistent AT recurrences progressively decreases with a high likelihood of established persistent AT within 9 months of onset [12]. It was also documented that AF burden increases progressively over the long term [13].

Patients with AT/AF are more likely to have adverse clinical outcomes, including a higher incidence of stroke, death, and subsequent $\mathrm{AF}$, than patients without AT/AF [1]. Analysis showed that in a relatively unselected population of patients with an arrhythmia detecting devices, daily AF burden is associated with an increased risk of ischaemic stroke or TIA even after adjustment for oral anticoagulants use [7]. These data add to current evidence that measuring daily AF burden may have important clinical relevance and support the search for specific thresholds of AF burden associated with a substantial increase in the risk of stroke $[15,16]$. Integration of AF presence/duration/burden has the potential to contribute to improved clinical risk stratification, and its aid to clinical decision-making should be tested prospectively [17]. About $25-30 \%$ of patients presenting with strokes have AF that was not previously recognised [18]. Furthermore, AF has been reported to be associated with substantial deterioration in attention and memory, even in the absence of a history of stroke and obvious defects on computer tomograms. The stroke risk conferred by paroxysmal AF has not been well characterised but has been arguably said to be the same as continuous AF. This establishes the need for better detection of atrial arrhythmias, and device-based monitoring gives us the possibility for continuous rhythm control compared to traditional ECG or 24- hour Holter ECG monitoring. Unfortunately, shortterm follow-up in our study resulted in absence of clinical events (e.g. stroke or death) so we could not assess risk of adverse events. Trends data do not allow us to define a "safe" AT/AF burden threshold that confers a risk no greater than that of zero AT/AF burden [4]. In this study there was also no threshold for AT/ AF burden episodes.

One of the study findings is that there are no clinical predictors of AT/AF except history of AF prior to implantation and use of $\beta$-blockers. Similarly, Healey et al. found no (other than older age) clinical predictors of pacemaker detected AT in a group of 445 patients with no previous history of AF and high percentage (50\%) of device-detected AT [2].

Among patients with symptomatic bradycardia and a history of atrial fibrillation, symptoms of atrial fibrillation often were not associated with documented AT (positive predictive value 17\% in the Strickberger SA study), and more than $90 \%$ of AT were clinically silent (AT/AF episodes without symptoms such as palpitations or dyspnoea reported by patients) [14]. In our study asymptomatic episodes occurred in seven patients ( $44 \%-3$ men and 4 women). Due to the symptoms reported by patients without recorded atrial burden, the association of episodes and symptoms is uncertain.

The results of this single-centre study may not be directly applicable to other practice settings. The study was limited to patients with pacemakers with normal ejection fraction. Another limitation is that some of our patients may have had silent paroxysmal AF prior to implantation; however, there is no reliable method to precisely identify such patients. Atrial undersensing can occur during AT/AF episodes, which can lead to failure to detect AT/AF burden episodes. Based on pacemaker diagnostics alone, it can also be difficult to differentiate AF from other forms of atrial arrhythmias. Finally, our study is limited by the short-term follow-up resulting in the absence of clinical events (e.g. stroke or death), and small sample size.

\section{Conclusions}

The diagnostic accuracy of pacemaker with an atrial lead is very high, and pacemaker-detection of AT is often the first paroxysmal AT diagnosis. Newly detected AT/AF during the first year after implantation was documented in more than $30 \%$ of patients, and no clinical characteristics in patients without history of AF prior to implantation were associated with pacemaker-detected AF. These data suggest that AT data should be collected from capable pacemakers to determine early treatment. Frequent follow-ups during the first year after implantation are very important for new diagnosis of arrhythmias thanks to the possibilities of patients' continuous monitoring by means of implantable cardiac devices. 


\section{Conflict of interest}

The authors declare no conflict of interest.

\section{References}

1. Glotzer TV, Hellkamp AS, Zimmerman J, Sweeney MO, Yee R, Marinchak R, Cook J, Paraschos A, Love J, Radoslovich G, Lee KL, Lamas GA; MOST Investigators. Atrial high rate episodes detected by pacemaker diagnostics predict death and stroke: report of the atrial diagnostics ancillary study of the mode selection trial (MOST). Circulation 2003; 107: 1614-9.

2. Healey JS, Martin JL, Duncan A, Connolly SJ, Ha AH, Morillo CA, Nair GM, Eikelboom J, Divakaramenon S, Dokainish $\mathrm{H}$. Pacemaker-detected atrial fibrillation in patients with pacemakers: prevalence, predictors and current use of oral anticoagulation. Can J Cardiol 2013; 29: 224-8.

3. Healey JS, Conolly SJ, Gold MR, Israel CW, Van Gelder IC, Capucci A, Lau CP, Fain E, Yang S, Bailleul C, Morillo CA, Carlson M, Themeles E, Kaufman ES, Hohnloser SH; ASSERT Investigators. Subclinical Atrial Fibrillation and the Risk of Stroke. N Engl J Med 2012; 366: 120-9.

4. Glotzer TV, Daoud EG, Wyse DG, Singer DE, Ezekowitz MD, Hilker C, Miller C, Qi D, Ziegler PD. The relationship between daily atrial tachyarrhythmia burden from implantable device diagnostics and stroke risk: the TRENDS study. Circ Arrhythm Electrophysiol 2009; 2 . 474-80.

5. http://www.heart.org/HEARTORG/Conditions/Arrhythmia/AboutArrhythmia/Why-Atrial-Fibrillation-AF-orAFib-Matters_UCM_423776_Article.jsp

6. U.S Department of Health and Human Services. 1984 Health Care Financing Administration. Available at: http://www.cms.hhs.gov/.

7. Epstein AE, DiMarco JP, Ellenbogen KA, Estes M, Freedman RA, Gettes LS, Gillinov AM, Gregoratos G, Hammill SC, Hayes DL, Hlatky MA, Newby LK, Page RL, Schoenfeld MH, Silka MJ, Stevenson LW, Sweeney MO. ACC/AHA/ HRS 2008 Guidelines for Device-Based Therapy of Cardiac Rhythm Abnormalities: Executive Summary. A Report of the American College of Cardiology/American Heart Association Task Force on Practice Guidelines (Writing Committee to Revise the ACC/AHA/NASPE 2002 Guideline Update for Implantation of Cardiac Pacemakers and Antiarrhythmia Devices) Developed in Collaboration With the American Association for Thoracic Surgery and Society of Thoracic Surgeons. J Am Coll Cardiol 2008; 51: 2085-105.

8. Pollak WM, Simmons JD, Interian A Jr, Atapattu SA, Castellanos A, Myerburg RJ, Mitrani RD. Clinical utility of intraatrial pacemaker stored electrograms to diagnose atrial fibrillation and flutter. Pacing Clin Electrophysiol 2001; 24: 424-9.

9. Boriani G, Glotzer TV, Santini M, West TM, De Melis M, Sepsi M, Gasparini M, Lewalter T, Camm JA, Singer DE. Device-detected atrial fibrillation and risk for stroke: an analysis of $>10000$ patients from the SOS AF project (Stroke prevention strategies based on atrial fibrillation information from implanted devices). Eur Heart J 2014; 35: 508-16.

10. Ziegler PD, Glotzer TV, Daoud EG, Singer DE, Ezekowitz MD, Hoyt RH, Koehler JL, Coles J Jr, Wyse DG. De- tection of previously undiagnosed atrial fibrillation in patients with stroke risk factors and usefulness of continuous monitoring in primary stroke prevention. Am J Cardiol 2012; 110: 1309-14.

11. Yedlapati N, Fisher JD. Pacemaker diagnostics in atrial fibrillation: limited usefulness for therapy initiation in a pacemaker practice. Pacing Clin Electrophysiol 2014; 37: 1189-97.

12. Nagarakanti R, Saksena S, Hettrick D, Koehler JL, Grammatico A, Padeletti L. Progression of new onset to established persistent atrial fibrillation: an implantable devicebased analysis with implications for clinical classification of persistent atrial fibrillation. J Interv Card Electrophysiol 2011; 32: 7-15

13. Gillis AM, Morck M. Atrial fibrillation after DDDR pacemaker implantation. J Cardiovasc Electrophysiol 2002; 13: 542-7.

14. Strickberger SA, Ip J, Saksena S, Curry K, Bahnson TD, Ziegler PD. Relationship between atrial tachyarrhytmias and symptoms. Heart Rhythm 2005; 2: 125-31.

15. Healey JS, Connolly SJ, Gold MR, Israel CW, Van Gelder IC, Capucci A, Lau CP, Fain E, Yang S, Bailleul C, Morillo CA, Carlson M, Themeles E, Kaufman ES, Hohnloser SH; ASSERT Investigators. Subclinical atrial fibrillation and the risk of stroke. N Engl J Med 2012; 366: 120-9.

16. Lamas G. How much atrial fibrillation is too much atrial fibrillation? N Engl J Med 2012; 366: 178-80.

17. Boriani G, Botto GL, Padeletti L, Santini M, Capucci A, Gulizia M, Ricci R, Biffi M, De Santo T, Corbucci G, Lip GY; Italian AT-500 Registry Investigators. Improving stroke risk stratification using the CHADS2 and CHA2DS2-VASc risk scores in patients with paroxysmal atrial fibrillation by continuous arrhythmia burden monitoring. Stroke 2011; 42: 1768-70.

18. Benezet-Mazuecos J, Rubio E, Farre J. Atrial high rate episodes in patients with dual-chamber cardiac implantable electronic devices: unmasking silent atrial fibrillation. Pace 2014; 37: 1080-6.

\section{Address for correspondence:}

\section{Anna Nowek MSc}

Department of Electrocardiology

Medical University of Lodz

ul. Pomorska 251, 92-213 Lodz, Poland

Phone: +48 505485595

E-mail: noweka@wp.pl 